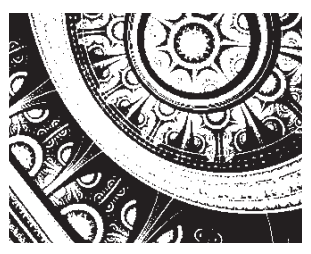

https://doi.org/10.5559/di.28.1.07

\title{
RESIDENTS' ATTITUDES TOWARD TOURISM DEVELOPMENT: A CASE STUDY OF THE FEDERATION OF BOSNIA AND HERZEGOVINA
}

Almir PEŠTEK

School of Economics and Business, Sarajevo

Lejla DIZDAREVIĆ

International University of Sarajevo, Sarajevo

Marijana GALIĆ

Federal Institute for Development Programming, Sarajevo

Melika ARIFHODŽIĆ

Faculty of Political Science, Sarajevo

UDK: $316.644(497.6): 338.48$

$$
338.486(497.6)
$$

Izvorni znanstveni rad

Primljeno: 9. 1. 2018.

This research focuses on analyzing residents' perception and attitude toward tourism development in the Federation of Bosnia and Herzegovina (FB\&H). For the purpose of this research, the existing models on residents' perception and attitudes were modified and a new theoretical model of six constructs was tested applying Confirmatory Factor Analysis (CFA). The dimensions of the model, perception of tourism management, perception of economic, social and environmental impacts, residents' satisfaction, support for further tourism development, were formed as latent variables, accompanied with a set of three or four consonant questions. The model suggests that the support for tourism development is indirectly stipulated by the perception of tourism management, and by economic, social and environmental impacts. Analyses have shown that 6 out of the 7 suggested hypotheses have been confirmed. The findings indicate that the residents of the FB\&H strongly support tourism development as they perceive it brings more positive impacts, which are greater than the actual governmental investment into the sector.

Keywords: residents' perception and attitudes, tourism development, local community, Federation of Bosnia and Herzegovina

$\triangle$ Lejla Dizdarević, International University of Sarajevo, Hrasnička cesta 15, 71000 Sarajevo,

Bosnia and Herzegovina. 
Over the past four decades, a considerable amount of research has been made on the local communities residents' attitude toward tourism development and its impact (Andereck \& Nyaupane, 2011; Andereck \& Vogt, 2000; Ap, 1992; Ap \& Crompton, 1993; Doxey, 1975; Gursoy, Chi, \& Dyer, 2010; Huh \& Vogt, 2008; Jurowski \& Gursoy, 2004; Liu \& Var, 1986; Nunkoo \& Ramkissoon, 2011; Nunkoo \& Gursoy, 2012; Pizam, 1978; Tosun, 2002; Vargas-Sánchez, Porras-Bueno, \& de los Ángeles Plaza-Mejía, 2011). These studies come as a follow-up to the massive increase of tourism which has been recorded in numerous destinations, constituting one of the most systematic and well-studied areas of tourism (McGehee \& Andereck, 2004), however, with secondary or less popular destinations not as much researched compared with mass tourism destinations (Ritchie \& Inkari, 2006).

This research was carried out on the territory of the Federation of Bosnia and Herzegovina (the FB\&H), one of the two entities of the state of Bosnia and Herzegovina (B\&H). Tourism statistics in the FB\&H record a continuous positive growth, showing that overall stays and overnights in 2016 doubled compared to those in 2010. The FB\&H appears as an interesting tourism destination, located in a favorable geographical position, at the intersection of the Alps, the Mediterranean and the Balkans. In the FB\&H there is still a lack of interest in the academic sphere as well as of public policies creators to include residents' attitudes in their analysis. Having in mind that this is the first research of this kind in the FB\&H, some of the models (Homsud \& Promsaard, 2015; Perdue, Long, \& Allen, 1990) on perceptions and attitudes of residents were modified and adapted. Analyzing previous research, recent data, and forecasts on tourism trends in the FB\&H, the authors came to the conclusion that the model should focus on the analysis of residents' satisfaction with tourism and their support for future tourism development in the FB\&H. In order to better understand and explain these goals, at the same time governed by numerous previous studies in the field, the authors analyzed residents' attitudes on the economic, socio-cultural and environmental impacts of tourism development. Researchers who analyzed these problems confirmed that there is a strong relationship between perceptions of tourism impacts in local residents and their support for further tourism development. In the last two decades researchers have analyzed more thoroughly the factors influencing perceived impacts and tourism development support (Gursoy \& Rutherford, 2004). The referred studies and works in the Literature Review have contributed to the modification and adaptation of our model for the FB\&H. 


\section{Literature review}

Understanding residents' attitudes on tourism development is crucial for successful sustainable tourism management and its development in general (Gursoy et al., 2010). A great number of authors who researched attitudes and residents' perception through Social Exchange Theory or Irridex (Doxey, 1975), developed models which subsequently tested individual relations between residents' perception of tourism management and, subsequently, their support for its further development. However, there still exists a range of untreated issues on residents' attitudes in countries in transition, where tourism development is undergoing its initial phase. Despite that, there are numerous studies dealing with the related topic but mainly focusing on certain issues, i.e. on factors that influence residents' perception in rural communities (Kosmaczewska, Thomas, \& Dias, 2016; Látková \& Vogt, 2012). Furthermore, the work of Dann (1988), in the form of bibliographical analysis, elaborates tourism research of the Caribbean while mentioning some of the related factors. Nevertheless, the aim of this research was to further the existing theoretical models of perception and attitudes of residents by using the model tested in the FB\&H. For this purpose, we adopted some of the existing models and additionally modified them, only to get the adjusted model which is tested. The operationalization of examined constructs and selection of variables that are relevant for each set of predictors are based on the integration of existing theoretical postulates and empirical validation within the Social Exchange Theory. Taking into account previous empirical research, we started this research with the assumption that the perception of tourism management has positive effects on residents' attitudes and their support for the further development of tourism.

\section{Residents' satisfaction and their support for further tourism development}

It is evident that the Social Exchange Theory, which was as a general sociological theory adapted by Ap (1992) for the purpose of examining relations between tourism participants, appears as the most functional and also very well applicable for the analysis of complex relations stemming from the tourism process in a certain local community (Faulkner \& Tideswell, 1997; Jurowsky, Uysal, \& Williams, 1997; Látková \& Vogt, 2012; Perdue et al., 1990; Gursoy et al., 2010; Lee, 2013). The Social Exchange Theory assumes that the exchange of social and material resources is a fundamental form of human interaction (McGehee \& Andereck 2004), and in that sense, many factors influencing residents to take a positive attitude are related to the fact whether they get direct or indirect benefits from tourism. 
DRUŠ. ISTRAŽ. ZAGREB GOD. 28 (2019), BR. 1, STR. 131-151

PEŠTEK, A. ET AL.: RESIDENTS' ATTITUDES..

\section{Tourism development management}

Local governments, policymakers, and businesses should have a deep understanding of the reasons for the support or decline of tourism development in the local community, because the success and sustainability of any development depends on active support of the local populations (Gursoy \& Rutherford, 2004; Gursoy et al., 2010). Such information can help planners select developments that can minimize negative impacts and maximize support for tourism development amongst certain members of the local population. In this modified model, we tested the perception of local residents on tourism management led by relevant governmental institutions and organizations. The importance of including analyses of residents' perception on governmental tourism management in this research has emerged from the fact that the relevant tourism governmental organizations have undertaken the process of reform in the FB\&H's tourism sector, which is induced by the recognition of tourism as key to the economic development of this entity.

\section{Residents' perception of economic,} socio-cultural and environmental impacts

The tourism phenomenon and its continuous growth initiate both positive and negative attitudes of local residents toward its further development, the roots of which could be found in the host's perception of tourism impacts on the local community (Ap, 1992; Andereck \& Nuyapane, 2011). As for the economic impacts of tourism, the majority of studies have confirmed a positive relationship between the perceived economic benefits and attitudes. When it comes to social and cultural impacts, research has shown mixed findings, both positive and negative. In the tourists' search for authenticity, questions are raised as to how this quest is successful and whether it brings real insight into the authentic culture of the locals (MacCannell, 1973; Mechkank, 2011), and how that quest affects it. Some authors stated that commoditization of culture takes place in order to artificially bring closer the authentic culture to the tourist (Greenwood, 1976). For others, the commoditization either helps preserve culture (Cohen, 1988), or even prompts residents engaged in tourism to utilize new channels of accessing traditions that may have persisted across centuries (Medina, 2003).

The impact of tourism on local culture is visible especially in cases where tourists are more dominant in the sense of financial and cultural power (Burns, 1999), which results in local people adapting to tourists' needs, attitudes and values and ultimately starting to imitate them (Nash, 1996). Along with the cultural, there are studies that confirm the negative 
DRUŠ. ISTRAŽ. ZAGREB GOD. 28 (2019), BR. 1 STR. 131-151

PEŠTEK, A. ET AL. RESIDENTS' ATTITUDES... social impacts of tourism. In his study of local residents' attitudes in an Australian town, Ross (1992) points out the negative attitudes which stemmed as a result of high real estate prices and high crime level. Several other authors have confirmed variables such as price increase of goods, services and real estate. Ap (1992), King, Pizam, and Milman (1993), Perdue et al., (1990), Pizam (1978) have pointed out the social disadvantages caused by tourism increase, such as hustle, heavy traffic and high crime rate, and Liu \& Var (1986) have also indicated the negative impacts on the natural environment. Assante, Wen, and Lottig, (2012) also found that residents recognize that economic benefits come with a cost to the environment, which ultimately diminishes residents' support for tourism development.

Apart from the negative socio-cultural impacts, residents reported positive attitude regarding tourism in the sense that it improves more recreation and park opportunities, improved quality of life (King et al., 1993; Perdue et al., 1990), improved appearance (Perdue et al., 1990), more facilities and a greater range of choice in services (Ritchie \& Inkari, 2006). Besides these, the social impacts of tourism may improve public utilities such as pavements, lighting, parking, litter control; opportunities for shopping can be increased (Gursoy \& Rutherford, 2004; Ritchie \& Inkari, 2006), but also the level of service in local shops and restaurants and landscaping can be improved (Pizam, 1978; Williams \& Lawson, 2001). Several other authors have confirmed variables such as price increase of goods, services and real estate.

\section{STUDY SETTING}

B\&H declared independence in 1992 and soon after experienced the war (1992-1995) that ended by signing the Dayton Peace Agreement. The agreement resulted with a solution where B\&H was composed of two entities (the Federation of Bosnia and Herzegovina and Republika Srpska) and the District of Brčko. The complex governmental structure affects the processes of development in general and in tourism as well (Alipour \& Dizdarevic, 2007).

However, tourism activities in the FB\&H in recent years are evidently increasing. According to official data, since 2010, the number of tourists has almost doubled. In 2010 407,000 tourists visited the FB\&H, and in 2016 the number increased to 812,000 tourists (Federal Institute of Statistics, 2017a). A distinct and turbulent history has created an almost unique spot symbolizing the meeting point of eastern and western civilizations (Nurković, 2009). The FB\&H is currently experiencing the initial phase of tourism development, but without an official strategic development plan. The Strategy of Tourism De- 
DRUŠ. ISTRAŽ. ZAGREB GOD. 28 (2019), BR. 1, STR. 131-151

PEŠTEK, A. ET AL.: RESIDENTS' ATTITUDES.. velopment was created in 2008 but was never officially adopted, while the development of the legal framework (Law on Tourism) has been under way since 2014. The country's complex structure, multi-ethnic nature, extensive bureaucracy and other related problems give rise to obstacles that are very difficult to overcome in any segment, particularly tourism.

\section{THE STUDY AND METHODOLOGY}

Various impacts of tourism certainly influence different segments of society and locality but ultimately it is the residents of a local community who are directly exposed to tourism development, which is a fact that should be considered in the process of establishing tourism development guidelines. So, it could be said that it is the residents of a local community that are the main carrier of tourism development in every tourism destination. In destinations that are still in the initial phase of their life-cycle (Butler, 1980), as it is the case with the FB\&H, empirical research has proved that residents' attitudes toward tourism development support are generally more positive in comparison to those in later stages of development.

Following the analysis of relevant literature, we modified the existing models on residents' perceptions and attitudes (Homsud \& Promsaard, 2015; Perdue et al., 1990), which we used to set up a theoretical model with six constructs (Image 1). The research tests applicability of the modified model on the territory of the FB\&H.

The model contains six dimensions: attitudes of tourism development support, perception of economic, social and ecological impacts, perception of tourism management and attitudes about further tourism development. The modified model assumes there is a direct influence of tourism management perception on the perception of economic, social and ecological impacts. The direct variable support for tourism development is considered to be under the direct influence of the residents' satisfaction about the tourism factor. The following variable definitions were applied in this research:

Tourism management perception relates to residents' perception of local authorities' management and tourism development creators. This variable contains three question sets or constructs.

Residents' satisfaction about tourism represents an expected additional value for the individual community member as to how tourism influences residents' pride. Furthermore, it explains whether residents consider that the overall positive tourism impacts outweigh the negative ones, and whether money invested in tourism is considered to be a good invest- 


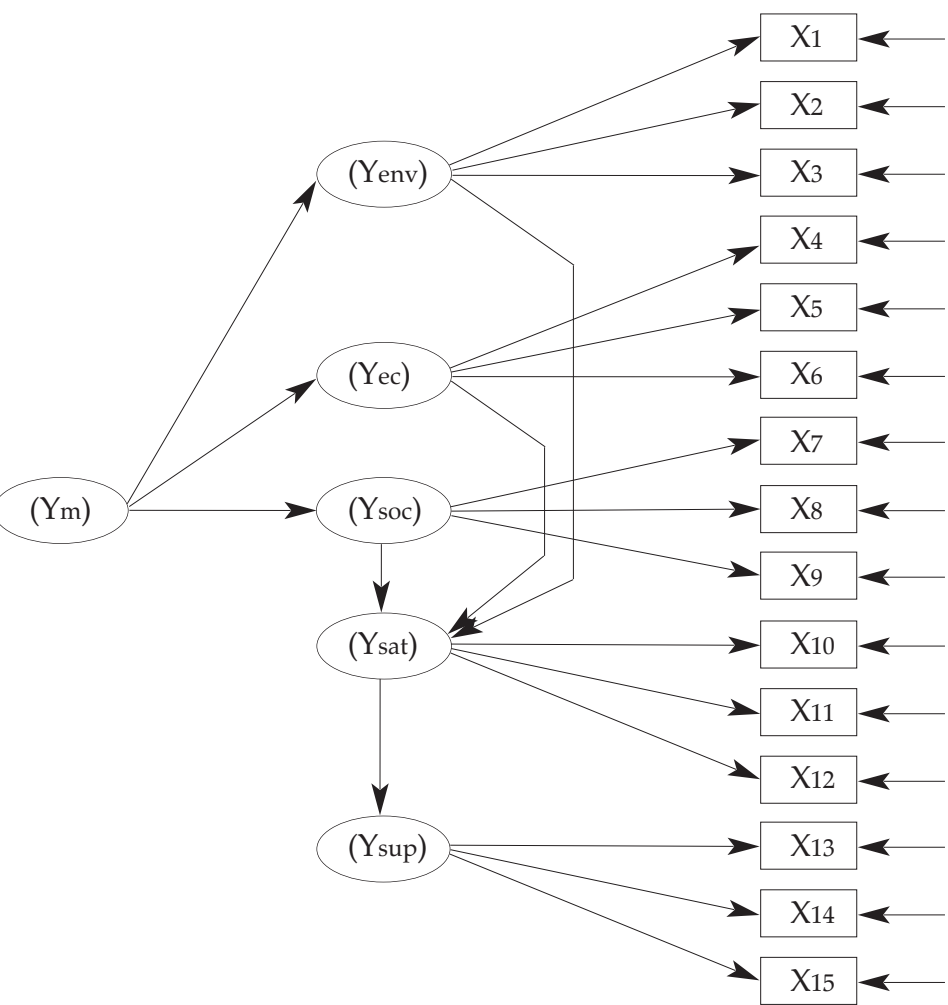

(1) IMAGE 1

Modified

theoretical model

Perceived governmental management of tourism (Ym)

Y1 Tourism has a great potential for the development of the local community in the future and it could be one of the leading economic activities.

Y2 Competent authorities and relevant ministries that deal with tourism planning harmonize the resident's needs and tourism development well.

Y3 I think that tourism organizations and competent authorities make good decisions for tourism development in the local community.

Perceived environmental impacts (Yenv)

X1 Tourism development disrupts life in the city/town center in terms of disturbing peaceful life and increasing crowdedness and hustle.

$\mathrm{X} 2$ Due to the increase in tourists' numbers there is more litter and garbage.

X3 Tourism in the FB\&H is developed in accordance with environmental protection.

Perceived economic impacts (Yec)

X4 Money that local communities spend on tourism development and improvement is a good and desirable investment.

X5 Overall benefits of tourism exceed its negative sides.

X6 Tourism development encourages the feeling of pride in local residents.

Perceived social impacts (Ysoc)

X7 Tourism creates opportunities of meeting new people and making new contacts and friendships.

X8 Tourists coming to the FB\&H are mainly familiar with its habits and culture of local residents.

X9 Local residents are familiar with the culture of visiting tourists. 
Residents' satisfaction (Ysat)

X10 Tourism development increases employment opportunities and creates new jobs in the FB\&H.

X11 Tourism contributes to increased real estate demand and price.

X12 Tourism development brings new facilities from which the overall community benefits.

Residents' support for further development (Ysup)

X13 I support the construction of new facilities and content that would attract more tourists.

X14 Growth of tourism produces good effects and strongly benefits the economy of the local community.

X15 I would like to see more tourists in the area I live.

Support for further tourism development is a latent variable reflecting residents' attitudes on support for development of new tourism facilities that are supposed to attract more tourists. This variable has four constructs.

Residents' perception of economic impacts of tourism is a set made of three constructs, or questions/statements sets that are related to residents' perception as to whether tourism contributes to new employment opportunities, real estate prices and overall economic benefits.

Residents' perception of social impacts of tourism is a latent variable created by a set of questions/statements through which residents explain their attitudes about tourists and whether they are generally satisfied with the social impacts of tourism. This statement set is related to the residents' perception of hospitability needed for tourists and whether tourism creates opportunities for meeting new people and cultures.

Residents' perception on environmental impacts of tourism is created as a latent variable comprised of a set of questions/ statements which give information on how residents perceive the influence of tourism on different environmental aspects such as traffic congestion in central city parts or the general attitude about the influence of tourism on the environment.

Each of the model's six dimensions were formed as a latent variable with three or four accompanying sets of questions for each variable. The model suggests that the support for tourism development is indirectly stipulated by the perception of tourism management, and by economic, social and environmental impacts. Besides, the model suggests that residents' satisfaction has a direct and positive influence on support for the further development of tourism.

We created a questionnaire for analyzing residents' perceptions and attitudes toward tourism development according to existing empirical research by Perdue et al. (1990), Ritchie and Inkari (2006), Ryan, Scotland, and Montgomery (1998), Li and Wan (2013) and Gilbert and Clark (1997).

The questionnaire was divided into two parts. The first part includes socio-demographic characteristics of respon- 
DRUŠ. ISTRAŽ. ZAGREB GOD. 28 (2019), BR. 1 STR. 131-151

PEŠTEK, A. ET AL. RESIDENTS' ATTITUDES... dents and it was purposefully constructed for the needs of this research. It contained four particles, where data on gender, age, education and employment were collected. The second part was created in 20 particles, or questions, that gave answers on how residents perceive tourism management, as well as economic, social and environmental impacts. In order to achieve the research objectives, it was also necessary to test a specific set of questions that are related to residents' satisfaction and support for further tourism development. The questions/statements correspond to a five-point Likert scale, used in most analyses dealing with residents' attitudes and perception of tourism ( 5 = Strongly Agree, 1 = Strongly Disagree).

For the purpose of testing the hypotheses and evaluating perceptions and attitudes of residents, we used a statistical procedure divided into two phases on two separate samples. The sampling frame included the population in all 10 Cantons in the FB\&H, having in mind that this entity is in the focus of tourism research for the purpose of passing a new Law on Tourism. The survey questionnaire was distributed throughout all ten Cantons, considering also different tourism possibilities and offers, as well as seasonality. The reason for questionnaire dispersion throughout all the Cantons was also linked to the numerous possibilities of analyses, for example whether the responses were related or influenced by geographic locations (Dillman, Smyth, Christian, \& O'Neill, 2010). The sample was selected using a convenience sample method from the FB\&H population, targeting both gender and persons over 18 years of age, therefore eligible in public policy creation through public hearings. The survey structure and procedures are based on online survey methodology (Messer \& Dillman, 2011; Dillman, Smyth, \& Christian, 2014). Email addresses were collected from various companies and organizations throughout all of the FB\&H Cantons. Contacts of unemployed persons were retrieved from the Federal Bureau of Employment, and students were contacted through Universities of Sarajevo, Mostar and Tuzla. This research excluded respondents from the tourism sector.

In the first phase, a pilot testing was implemented aimed to eliminate possible deficiencies in the questionnaire, as well as in techniques that are applied during the survey. The questionnaire was sent in the period from August 2016 to January 2017 to 400 addresses, of which 276 respondents (69\%) gave valid responses.

According to the results of our pilot research (276 respondents), we conducted tests of reliability and normality of independent and dependent variables. Values of Cronbach's alpha predictor and dependent variables are shown in Table 1. 
DRUŠ. ISTRAŽ. ZAGREB GOD. 28 (2019), BR. 1,
STR. 131-151

PEŠTEK, A. ET AL.: RESIDENTS' ATTITUDES...

$\rightarrow$ TABLE

Values of Cronbach's alpha predictor and dependent variables

\begin{tabular}{llrrr}
\hline \multirow{2}{*}{ Endogenous } & Exogenous & $\begin{array}{r}\text { Cronbach's } \\
\text { alpha }\end{array}$ & Skewness & Kurtosis \\
\hline Yenv & X1 & 0.932 & -1.21837 & 0.577 \\
& X2 & 0.932 & -1.26916 & 0.512 \\
Yec & X3 & 0.931 & -1.74924 & 2.274 \\
& X7 & 0.939 & 2.266144 & 6.251 \\
& X8 & 0.937 & 0.429283 & -0.605 \\
Ysoc & X9 & 0.933 & -0.88657 & 0.039 \\
& X4 & 0.931 & -1.60815 & 1.841 \\
& X5 & 0.933 & -0.73378 & -0.253 \\
Ysat & X6 & 0.933 & -0.71537 & -0.135 \\
& X10 & 0.933 & -0.62254 & -0.203 \\
& X11 & 0.934 & -0.50607 & -0.425 \\
Ysup & X12 & 0.931 & -1.2129 & 0.590 \\
& X13 & 0.932 & -0.92822 & -0.040 \\
& X14 & 0.932 & -1.3605 & 0.910 \\
Ym & X15 & 0.932 & -1.38772 & 0.923 \\
& Y1 & 0.936 & 0.485756 & 0.063 \\
& Y2 & 0.938 & 0.966774 & 0.744 \\
& Y3 & 0.937 & 0.537607 & -0.147 \\
\hline
\end{tabular}

Using the same methodology as in the pilot testing, the questionnaire was sent to 480 email addresses and got the response of $404(84 \%)$.

There is an evident disproportion between the number of female $(56.1 \%)$ and male respondents $(43.8 \%)$. Most of the respondents have a university degree $(58.67 \%) .17 .8 \%$ of the respondents are between age 18-25, 38.7\% are employed and $25.99 \%$ are students.

It is expected that the results of this research bring guidelines needed for future steps in order to influence a broader involvement of the community into the tourism planning process, taking into consideration principles of sustainability. Doxey's (1975) postulate about euphoria in local residents during the initial stage of tourism was accepted, as well as Social Exchange Theory's claims about positive relations between economic impacts and residents' satisfaction. Also, at the beginning of tourism development there is insufficient compliance of tourism development with the environment, so we assume that residents' perception of environmental impacts has a negative relation to residents' satisfaction, having in mind that the local community often bears the consequences of environmental degradation that is caused by tourists' exploitation (Beeton, 2006; Holden, 2009).

Based on analyses of the previous research in the field, it is anticipated that: 
DRUŠ. ISTRAŽ. ZAGREB GOD. 28 (2019), BR. 1 STR. 131-151

PEŠTEK, A. ET AL. RESIDENTS' ATTITUDES...

TABLE 2

Demographics of the sample $(n=404)$ and the FB\&H

\begin{tabular}{llrrr}
\hline \multirow{2}{*}{ Demographics } & & & Sample & FB\&H \\
Gender & & $\mathrm{n}$ & $\%$ & $\%$ \\
\hline \multirow{3}{*}{ Occupation } & Male & 177 & 43.8 & 49.03 \\
& Female & 227 & 56.1 & 50.97 \\
& Employee & 155 & 38.37 & 33.90 \\
& Student & 105 & 25.99 & 2.92 \\
& Housewife & 57 & 14.11 & 5.09 \\
Age & Unemployed & 58 & 14.36 & 14.94 \\
& Retired & 29 & 7.18 & 18.54 \\
& 18-25 & 69 & 17.08 & 11.03 \\
& 26-35 & 45 & 11.14 & 14.59 \\
& 36-45 & 48 & 11.88 & 14.11 \\
& $46-55$ & 29 & 7.18 & 15.40 \\
& 56-65 & 54 & 13.37 & 12.28 \\
& 65+ & 37 & 9.16 & 11.96 \\
Canton of residence & High school & 167 & 41.34 & 51.14 \\
& University degree & 237 & 58.67 & 13.15 \\
& Sarajevo & 69 & 17.08 & 18.86 \\
& Zenica-Doboj & 45 & 11.14 & 16.23 \\
& Tuzla & 48 & 11.88 & 19.91 \\
& Central Bosnia & 29 & 7.18 & 11.33 \\
& Herzegovina-Neretva & 54 & 13.37 & 9.84 \\
& Canton 10 & 37 & 9.16 & 3.67 \\
& Posavina & 21 & 5.20 & 1.89 \\
& West Herzegovina & 30 & 7.43 & 4.22 \\
& Una-Sana & 45 & 11.14 & 12.18 \\
& Podrinje & 26 & 6.44 & 1.05 \\
& & & &
\end{tabular}

Source: Primary data, Federal Institute for Statistics (2017b)

H1: The perception of tourism management has a negative relationship with environmental impacts.

H2: The residents' perception of tourism management has a positive relationship with economic impacts.

H3: The perception of tourism management creates a positive relationship with social impacts.

H4: The perception of environmental impacts has a positive relationship with residents' satisfaction with tourism development.

H5: The perception of social impacts has a positive relationship with residents' satisfaction with tourism development.

H6: The perception of economic impacts has a positive relationship with residents' satisfaction with tourism development.

H7: The residents' satisfaction has a positive and statistically significant relationship with their support for further tourism development. 


\section{RESEARCH FINDINGS AND DISCUSSION}

Following the questionnaire implemented on 404 respondents, we conducted tests of reliability and normality of independent and dependent variables. Values of Cronbach's alpha predictor and dependent variables confirmed that the chosen variables were valid.

The main constructs in the model were tested with Con-

(1) TABLE 3

The measurement model firmatory factor analysis (CFA), or path analysis. Table 3 also shows that all AVE values were above 0.5.

\begin{tabular}{|c|c|c|c|c|}
\hline Item & $\begin{array}{r}\text { Std. } \\
\text { loading }\end{array}$ & t-value & AVE & $\mathrm{CR}$ \\
\hline $\begin{array}{l}\text { Money that local communities spend on tourism development } \\
\text { and improvement is a good and desirable investment. }\end{array}$ & 0.84 & 20.38 & & \\
\hline Overall benefits of tourism exceed its negative sides. & 0.88 & 22.04 & 0.757367 & 0.971353 \\
\hline $\begin{array}{l}\text { Tourism development encourages the feeling } \\
\text { of pride in local residents. }\end{array}$ & 0.89 & 22.58 & & \\
\hline $\begin{array}{l}\text { Tourism has a great potential for the development } \\
\text { of the local community in future and it could be } \\
\text { one of the leading economic activities. }\end{array}$ & 0.65 & 12.35 & & \\
\hline $\begin{array}{l}\text { Competent authorities and relevant ministries that deal } \\
\text { with tourism planning harmonize residents' needs and } \\
\text { tourism development well. }\end{array}$ & 0.68 & 12.88 & 0.463000 & 0.720923 \\
\hline $\begin{array}{l}\text { I think that tourism organizations and competent } \\
\text { authorities make good decisions for tourism } \\
\text { development in the local community. }\end{array}$ & 0.71 & 13.17 & & \\
\hline $\begin{array}{l}\text { Tourism development disrupts life in the city/town } \\
\text { center in terms of disturbing peaceful life and } \\
\text { increasing crowdedness and hustle. }\end{array}$ & 0.88 & 22.2 & & \\
\hline $\begin{array}{l}\text { Due to an increase in tourists' numbers there is more } \\
\text { litter and garbage. }\end{array}$ & 0.87 & 21.73 & 0.774467 & 0.911512 \\
\hline $\begin{array}{l}\text { Tourism in the FB\&H is developed in accordance with } \\
\text { environmental protection. }\end{array}$ & 0.89 & 22.55 & & \\
\hline $\begin{array}{l}\text { Tourists coming to the FB\&H are mainly familiar with the } \\
\text { habits and culture of local residents. }\end{array}$ & 0.89 & 21.57 & 0.582467 & 0.785227 \\
\hline Local residents are familiar with the culture of visiting tourists. & 0.92 & 23.32 & & \\
\hline $\begin{array}{l}\text { Tourism development increases employment opportunities } \\
\text { and creates new jobs in the FB\&H. }\end{array}$ & 0.87 & 20.87 & & \\
\hline Tourism contributes to increased real estate demand and price. & 0.88 & 21.06 & 0.634467 & 0.835498 \\
\hline $\begin{array}{l}\text { Tourism development brings new facilities from which the } \\
\text { overall community benefits. }\end{array}$ & 0.61 & 13.9 & & \\
\hline $\begin{array}{l}\text { I support the construction of new facilities and content } \\
\text { that would attract more tourists. }\end{array}$ & 0.87 & 21.62 & & \\
\hline $\begin{array}{l}\text { Growth of tourism produces good effects and strongly } \\
\text { benefits the economy of the local community. }\end{array}$ & 0.89 & 22.51 & 0.708867 & 0.879094 \\
\hline I would like to see more tourists in the area I live. & 0.76 & 17.63 & & \\
\hline
\end{tabular}


DRUŠ. ISTRAŽ. ZAGREB GOD. 28 (2019), BR. 1 STR. $131-151$

PEŠTEK, A. ET AL. RESIDENTS' ATTITUDES...

(1) TABLE 4 Model
The method of probability assessment was used in order to establish reliability and validity via composite reliability, which needs to be higher than 0.70 as set in the theory (Nunnally \& Bernstein, 1994). Although standard loadings on some items are less than 0.7 , like Tourism has a great potential for the development of the local community in future and it could be one of the leading economic activities (0.65) and Competent authorities and relevant ministries that deal with tourism planning harmonize residents' needs and tourism development well (0.68), we didn't exclude them, since CFA analysis showed that the measured variables represented the number of constructs well. Chi-square = 328.16 , degrees of freedom $=120$, comparative fit index $(\mathrm{CFI})=$ 0.98 , goodness of fit index $(\mathrm{GFI})=0.92$, root mean square residual $(R M R)=0.069$, standardized $R M R=0.052$. Variables that are included into multiple regression analysis may have certain measurement errors, which can cause certain problems during the interpretation of results. The starting model Cmin $/ \mathrm{df}=4.79, \mathrm{CFI}=0.960, \mathrm{GFI}=0.850, \mathrm{RMR}=0.079, \mathrm{a}$ RMSEA $=0.097$, which shows that the level of model suitability is within acceptable borders.

In table 4, the relationships and expected direction of dependent and independent variables are presented.

\begin{tabular}{|c|c|c|c|c|}
\hline \multicolumn{2}{|l|}{ Effects } & \multirow{2}{*}{$\begin{array}{l}\text { S. est. } \\
-0.06\end{array}$} & \multicolumn{2}{|c|}{$Z$-value } \\
\hline $\begin{array}{l}\text { Perception of government } \\
\text { tourism management }\end{array}$ & $\begin{array}{l}\text { Perceived environ- } \\
\text { mental impacts }\end{array}$ & & 1.02 & Not supported \\
\hline $\begin{array}{l}\text { Perception of government } \\
\text { tourism management }\end{array}$ & $\begin{array}{l}\text { Perceived economic } \\
\text { impacts }\end{array}$ & $0.94^{* * *}$ & 19.95 & Supported \\
\hline $\begin{array}{l}\text { Perception of government } \\
\text { tourism management }\end{array}$ & Perceived social impacts & $0.84^{* * *}$ & 6.42 & Supported \\
\hline Perceived environmental impact & Residents' satisfaction & $0.23^{* * *}$ & 4.97 & Supported \\
\hline Perceived social impact & Residents' satisfaction & $0.70^{* *}$ & 2.58 & Supported \\
\hline Perceived economic impact & Residents' satisfaction & $0.23^{* * *}$ & 5.37 & Supported \\
\hline Residents' satisfaction & Residents' support & $0.85^{* * *}$ & 14.79 & Supported \\
\hline
\end{tabular}

The structural model confirmed 6 out of 7 suggested hypotheses. Six of all the independent variables were statistically significant.

Hypothesis 1 - The residents' perception is that tourism management negatively influences environmental impacts. This hypothesis is not supported, the relationship is negative with the coefficient 0.062. Jurowski et al. (1997) confirmed that residents perceive the economic and social impacts positively, whereas the environmental ones negatively. 
DRUŠ. ISTRAŽ. ZAGREB GOD. 28 (2019), BR. 1, STR. 131-151

PEŠTEK, A. ET AL.: RESIDENTS' ATTITUDES..
Hypothesis 2 - Residents perceive that efficient governmental management has a positive influence on economic impacts of tourism, which was supported by the coefficient 0.94 Furthermore, the hypothesis supports a relationship recognized by Wong (1996) - tourism planning and management is indispensable for residents' satisfaction, which consequently results in positive effects on economic impacts. These results are also confirmed by Ko \& Stewart (2002) and Faulkner \& Tideswell (1997).

Hypothesis 3 - Residents perceive that tourism management creates a positive relationship with social impacts, which is supported by the coefficient 0.84 . Social impacts of tourism affect the local community and local residents and the quality of their life through an increase of tourism and their direct and indirect associations with tourists. Positivity in that sense may be viewed in advanced services and enhanced restaurants landscaping (Pizam, 1978; Williams \& Lawson, 2001), and improved opportunities for shopping (Gursoy \& Rutherford, 2004; Ritchie \& Inkari, 2006).

Hypothesis 4 - has investigated the influence of environmental impact perception on satisfaction of the wider community. Positive influence on overall residents' satisfaction is the hypothesis that is supported by 0.23 . Residents that positively perceive the influence of environmental impacts will have greater community satisfaction. These stands are confirmed by the majority of authors (Cavus \& Tanrisevdi, 2003; Cohen, 1988; Doxey, 1975; Dyer, Gursoy, \& Sharma, 2007; Faulkner \& Tideswell, 1997; Ko \& Stewart, 2002).

Hypothesis 5 - Social impacts have a positive relationship with residents' satisfaction, and it is supported by the coefficient 0.70 . These results correlate with previous analyses confirmed in the works of Doxey (1975) and Perdue et al. (1990).

Hypothesis 6 - Economic impacts have a positive relation with residents' satisfaction, which is supported by the coefficient 0.23 . Numerous studies have already proved that residents who are economically dependent on tourism develop positive attitudes and manifest satisfaction (Pizam, 1978; Brougham, \& Butler, 1981).

Hypothesis 7 - foresees that overall residents' satisfaction will positively influence residents' attitudes and the support for tourism development, which is supported by the coefficient 0.85 . Such a result confirms the relation recognized by Cavus \& Tanrisevdi (2003), that residents who feel involved in the process of tourism planning are favorable toward further tourism development. Although this research did not test the question set on whether residents consider themselves sufficiently involved in tourism planning activities, the majority 
DRUŠ. ISTRAŽ. ZAGREB GOD. 28 (2019), BR. 1 STR. 131-151

PEŠTEK, A. ET AL.: RESIDENTS' ATTITUDES... of authors find it necessary for sustainable tourism development. Inclusion of the wider community certainly increases positive and favorable feelings (Dyer et al., 2007; Ko \& Stewart, 2002). The relationships between tourism support and other variables, such as residents' satisfaction, were discussed considerably in research. It is confirmed that satisfaction is positively related with the variable support for tourism development. Some analyses showed that these variables were not statistically significant (Woosnam, 2012). A positive connection was confirmed in the relationship between community perception and support for tourism (Nicholas, Thapa, \& Ko, 2009), whereas Perdue et al. (1990) confirmed a negative relationship existing between variables.

About $83 \%$ of all respondents agree that "Tourism development increases employment opportunities and creates new jobs", without significant difference between Cantons. Some $47 \%$ of respondents agree that "Growth of tourism produces good effects and strongly benefits the economy of the local community", and about $81 \%$ agree with "I would like to see more tourists in the area I live".

$47 \%$ of respondents confirm that "Money that local communities spend on tourism development and improvement is a good and desirable investment".

The majority of the respondents agree that "Overall benefits of tourism exceed its negative sides", most of them from the Herzegovina-Neretva Canton (28\%). A greater part of the respondents support "Tourism development disrupts life in the city/town center in terms of disturbing peaceful life and increasing crowdedness and hustle", mostly from the Sarajevo Canton (22\%).

The majority of the respondents, mostly from the Sarajevo Canton, do not find that "Tourism is developed in accordance with environmental protection".

The distribution of answers is similar in all cantons when it comes to "Tourism creates opportunities for meeting new people and making new contacts and friendships".

\section{CONCLUSION}

With the recent expansion of tourism, B\&H is becoming an emerging factor on the international competitive market. In view of future tourism development in the country, it is particularly important to examine and understand residents' perception and attitudes.

The results of analysis have shown that considering the suggested hypotheses, 6 out of 7 hypotheses have been confirmed and six out of all the variables are statistically significant. The obtained data have shown that the residents of the FB\&H strongly support tourism development. This support 
DRUŠ. ISTRAŽ. ZAGREB GOD. 28 (2019), BR. 1, STR. 131-151

PEŠTEK, A. ET AL.: RESIDENTS' ATTITUDES.. confirms the Social Exchange Theory's main postulates, confirming its ideas of positive perception of the local population toward tourism development only in the case if it brings more benefits than cost.

Efficient government management has a positive effect on economic impacts, and governmental tourism management and planning are crucial for residents' satisfaction. The current government structure in $\mathrm{B} \& \mathrm{H}$ and the $\mathrm{FB} \& \mathrm{H}$ suffers from a lack of vertical and horizontal coordination amongst institutions, and is considered to be the factor hampering the development of the national economy, including the tourism sector (Peštek \& Činjarević, 2014). In the absence of a national and entity policy for tourism development, it is difficult to formulate effective development strategies in B\&H and the FB\&H. Over previous years, development activities in tourism have been managed in an uncoordinated manner without a strategic long-term orientation. This underlines the significance of the study for tourism policy creators. The research results and theoretical framework confirm the need for urgent legislation and creation of strategic documents that are aimed at regulating the tourism sector, thus establishing sustainable tourism development and an efficient destination management framework.

The results additionally confirm and contribute to a better understanding of the Social Exchange Theory, defined by the model, taking into consideration the model's various impacts (economic, socio-cultural and environmental) related to the respondents' support. The analysis of the central model showed that the "Perception on government tourism management" is most strongly affected by perceived social impacts, followed by economic ones, whereas environmental perception does not have a statistically significant influence. However, it should be noted that relations between "Residents' satisfaction" and each of the impacts may vary depending on the context. In the FB\&H example, "Residents' satisfaction" is under a weaker influence of environmental and economic impacts, whereas social impacts are more distinguished.

This research had several limitations which need to be solved in future research. Firstly, the study was conducted only on the territory of the FB\&H, and not the whole territory of B\&H. In further research it will also be necessary to analyze data relating to residents' attitudes throughout several years, so that the model could be better explained and understood. Interviews and focus groups with some of the residents could be of help in order to support/reject the conclusions acquired by the use of the SEM technique. 
Alipour, H., \& Dizdarevic, L. (2007). A conceptual sustainability approach to tourism planning and development in post-war Bosnia and Herzegovina $(\mathrm{BiH})$. Tourism and Hospitality Planning $\mathcal{E}$ Development, 4(3), 211-230. https://doi.org/10.1080/14790530701778202

Andereck, K. L., \& Nyaupane, G. P. (2011). Exploring the nature of tourism and quality of life perceptions among residents. Journal of Travel Research, 50(3), 248-260. https://doi.org/10.1177/0047287510362918

Andereck, K. L., \& Vogt, C. A. (2000). The relationship between residents' attitudes toward tourism and tourism development options. Journal of Travel Research, 39(1), 27-36. https://doi.org/10.1177/0047287 50003900104

Ap, J. (1992). Residents' perceptions on tourism impacts. Annals of Tourism Research, 19(4), 665-690. https://doi.org/10.1016/0160-7383(92) 90060-3

Ap, J., \& Crompton, J. L. (1993). Residents' strategies for responding to tourism impacts. Journal of Travel Research, 32(1), 47-50. https://doi. org/10.1177/004728759303200108

Assante, L. M., Wen, H. I., \& Lottig, K. J. (2012). Conceptualization of modeling resident attitudes on the environmental impacts of tourism: A case study of Oahu, Hawaii. Tourism Planning $\mathcal{E}$ Development, 9(2), 101-118. https://doi.org/10.1080/21568316.2011.631354

Beeton, S. (2006). Community Development through Tourism. Collingwood, Victoria: Landlinks Press.

Brougham, J. E., \& Butler, R. W. (1981). A segmentation analysis of resident attitudes to the social impact of tourism. Annals of Tourism Research, 8(4), 569-590. https://doi.org/10.1016/0160-7383(81)90042-6

Burns, P. (1999). An introduction to tourism and anthropology. London: Routledge.

Butler, R. W. (1980). The concept of a tourist area cycle of evolution: Implications for management of resources. The Canadian Geographer/ Le Géographe canadien, 24(1), 5-12. https://doi.org/10.1111/j.1541-0064. 1980.tb00970.x

Cavus, S., \& Tanrisevdi, A. (2003). Residents' attitudes toward tourism development: A case study in Kusadasi, Turkey. Tourism Analysis, 7(3-1), 259-269. https://doi.org/10.3727/108354203108750102

Cohen, E. (1988). Authenticity and commoditization in tourism. Annals of Tourism Research 15(3), 371-386. https://doi.org/10.1016/01607383(88)90028-X

Dann, G. M. (1988). Tourism research on the Caribbean: An evaluation. Leisure Sciences, 10(4), 261-280. https://doi.org/10.1080/01490408809512196

Dillman, D. A., Smyth, J. D., \& Christian, L. M. (2014). Internet, phone, mail and mixed-mode surveys: The tailored design method, 4th Edition. Hoboken, NJ: John Wiley \& Sons Inc.

Dillman, D. A., Smyth, J. D., Christian, L. M., \& O'Neill, A. (2010). Using the Internet to survey small towns and communities: Limitations and possibilities in the early 21st century. American Behavioral Scientist 53(9), 1423-1448. https://doi.org/10.1177/0002764210 361695 
DRUŠ. ISTRAŽ. ZAGREB GOD. 28 (2019), BR. 1, STR. $131-151$

PEŠTEK, A. ET AL.: RESIDENTS' ATTITUDES...
Doxey, G. V. (1975). A causation theory of visitor-resident irritants: Methodology and research inferences. In Travel and Tourism Research Association 6th Annual Conference Proceedings, San Diego, September (pp. 195-198).

Dyer, P., Gursoy, D., Sharma, B., \& Carter, J. (2007). Structural modeling of resident perceptions of tourism and associated development on the Sunshine Coast, Australia. Tourism Management, 28(2), 409-422. https://doi.org/10.1016/j.tourman.2006.04.002

Faulkner, B., \& Tideswell, C. (1997). A framework for monitoring community impacts of tourism. Journal of Sustainable Tourism, 5(1), 3-28. https://doi.org/10.1080/09669589708667273

Federal Institute of Statistics (2017a). Statistical Yearbook of the Federation of Bosnia and Herzegovina. Available at http://fzs.ba/index.php/pu blikacije/statisticki-godisnjaciljetopisi/

Federal Institute of Statistics (2017b). 2013 Population Census in Bosnia and Herzegovina. Available at http://fzs.ba/index.php/popis-stanovnistva/ popis-stanovnistva-2013/konacni-rezultati-popisa-2013/

Gilbert, D., \& Clark, M. (1997). An exploratory examination of urban tourism impact, with reference to residents' attitudes, in the cities of Canterbury and Guildford. Cities, 14(6), 343-352. https://doi.org/10. 1016/S0264-2751(97)00025-5

Greenwood, D. J. (1976). Tourism as an agent of change: A Spanish Basque case. Annals of Tourism Research, 3(3), 128-142. https://doi.org/ 10.1016/0160-7383(76)90005-0

Gursoy, D., \& Rutherford, D. G. (2004). Host attitudes toward tourism: An improved structural model. Annals of Tourism Research, 31(3), 495-516. https://doi.org/10.1016/j.annals.2003.08.008

Gursoy, D., Chi, C. G., \& Dyer, P. (2010). Locals' attitudes toward mass and alternative tourism: The case of Sunshine Coast, Australia. Journal of Travel Research, 49(3), 381-394. https://doi.org/10.1177/0047 287509346853

Homsud, N., \& Promsaard, S. (2015). The effects of residents' image and perceived tourism impact to residence satisfaction and support: Case study of Hua-HinPrachubkirikhan. The 2015 WEI International Academic Conference Proceedings.

Holden, A. (2009). The environment-tourism nexus: Influence of market ethics. Annals of Tourism Research, 36(3), 373-389. https://doi.org/10. 1016/j.annals.2008.10.009

Huh, C., \& Vogt, C. A. (2008). Changes in residents' attitudes toward tourism over time: A cohort analytical approach. Journal of Travel Research, 46(4), 446-455. https://doi.org/10.1177/0047287507308327

Jurowski, C., \& Gursoy, D. (2004). Distance effects on residents' attitudes toward tourism. Annals of Tourism Research, 31(2), 296-312. https://doi.org/10.1016/j.annals.2003.12.005

Jurowski, C., Uysal, M., \& Williams, D. R. (1997). A theoretical analysis of host community resident reactions to tourism. Journal of Travel Research, 36(2), 3-11. https://doi.org/10.1177/004728759703600202

King, B., Pizam, A., \& Milman, A. (1993). Social impacts of tourism: Host perceptions. Annals of Tourism Research, 20(4), 650-665. https://doi. org/10.1016/0160-7383(93)90089-L 
DRUŠ. ISTRAŽ. ZAGREB GOD. 28 (2019), BR. 1, STR. $131-151$

PEŠTEK, A. ET AL. RESIDENTS' ATTITUDES...
Ko, D. W., \& Stewart, W. P. (2002). A structural equation model of residents' attitudes for tourism development. Tourism Management, 23(5) 521-530. https://doi.org/10.1016/S0261-5177(02)00006-7

Kosmaczewska, J., Thomas, R., \& Dias, F. (2016). Residents' perceptions of tourism and their implications for policy development: Evidence from rural Poland. Community Development, 47(1), 136-151. https://doi.org/10.1080/15575330.2015.1110189

Látková, P., \& Vogt, C. A. (2012). Residents' attitudes toward existing and future tourism development in rural communities. Journal of Travel Research, 51(1), 50-67. https://doi.org/10.1177/0047287510394193

Lee, T. H. (2013). Influence analysis of community resident support for sustainable tourism development. Tourism Management, 34, 37-46. https://doi.org/10.1016/j.tourman.2012.03.007

Li, X., \& Wan, Y. K. P. (2013). Residents' attitudes toward tourism development in Macao: A path model. Tourism Analysis, 18(4), 443-455. https://doi.org/10.3727/108354213X13736372326073

Liu, J. C., \& Var, T. (1986). Residents attitudes toward tourism impacts in Hawaii. Annals of Tourism Research, 13(2), 193-214. https://doi.org/10. 1016/0160-7383(86)90037-X

MacCannell, D. (1973). Staged authenticity: Arrangements of social space in tourist settings. American Journal of Sociology, 79(3), 589-603. https://doi.org/10.1086/225585

McGehee, N. G., \& Andereck, K. L. (2004). Factors predicting rural residents' support of tourism. Journal of Travel Research, 43(2), 131-140. https://doi.org/10.1177/0047287504268234

Medina, L. K. (2003). Commoditizing culture: Tourism and Maya identity. Annals of Tourism Research, 30(2), 353-368. https://doi.org/10. 1016/S0160-7383(02)00099-3

Meschkank, J. (2011). Investigations into slum tourism in Mumbai: Poverty tourism and the tensions between different constructions of reality. Geojournal, 76(1), 47-62. https://doi.org/10.1007/s10708-010-9401-7

Messer, B. L., \& Dillman, D. A. (2011). Surveying the general public over the Internet using address-based sampling and mail contact procedures. Public Opinion Quarterly, 75(3), 429-57. https://doi.org/10. 1093/poq/nfr021

Nicholas L., Thapa B., \& Ko Y. (2009). Residents' perspectives of a world heritage site: The Pitons Management Area, St. Lucia. Annals of Tourism Research 36(3), 390-412. https://doi.org/10.1016/j.annals. 2009.03.005

Nash, D. (1996). Anthropology of tourism. Kidlington: Pergamon.

Nunnally, J. C., \& Bernstein, I. H. (1994). Psychometric theory (3rd Ed.). New York, NY: McGraw-Hill.

Nunkoo, R., \& Gursoy, D. (2012). Residents' support for tourism: An identity perspective. Annals of Tourism Research, 39(1), 243-268. https://doi.org/10.1016/j.annals.2011.05.006

Nunkoo, R., \& Ramkissoon, H. (2011). Developing a community support model for tourism. Annals of Tourism Research, 38(3), 964-988. https://doi.org/10.1016/j.annals.2011.01.017 
DRUŠ. ISTRAŽ. ZAGREB GOD. 28 (2019), BR. 1, STR. $131-15$

PEŠTEK, A. ET AL.: RESIDENTS' ATTITUDES...
Nunkoo, R., \& Ramkissoon, H. (2011). Residents' satisfaction with community attributes and support for tourism. Journal of Hospitality $\mathcal{E}$ Tourism Research, 35(2), 171-190. https://doi.org/10.1177/109634801 0384600

Nurković, R. (2009). Influence of tourism on the regional development of Bosnia and Herzegovina. International Journal of Euro-Mediterranean Studies, 2, 201-215.

Perdue, R. R., Long, P. T., \& Allen, L. (1990). Resident support for tourism development. Annals of Tourism Research, 17(4), 586-599. https://doi.org/10.1016/0160-7383(90)90029-Q

Peštek, A., \& Činjarević, M. (2014). Tourist perceived image of local cuisine: The case of Bosnian food culture. British Food Journal, 116(11), 1821-1838. https://doi.org/10.1108/BFJ-01-2014-0046

Pizam, A. (1978). Tourism's impacts: The social costs to the destination community as perceived by its residents. Journal of Travel Research, 16(4), 8-12. https://doi.org/10.1177/004728757801600402

Ritchie, B. W., \& Inkari, M. (2006). Host community attitudes toward tourism and cultural tourism development: The case of the Lewes District, Southern England. International Journal of Tourism Research, 8(1), 27-44. https://doi.org/10.1002/jtr.545

Ross, G. F. (1992). Resident perceptions of the impact of tourism on an Australian city. Journal of Travel Research, 30(3), 13-17. https://doi. org/10.1177/004728759203000302

Ryan, C., Scotland, A., \& Montgomery, D. (1998). Resident attitudes to tourism development - A comparative study between the Rangitikei, New Zealand and Bakewell, United Kingdom. Progress in Tourism and Hospitality Research, 4(2), 115-130. https://doi.org/10.1002/ (SICI)1099-1603(199806)4:2<115::AID-PTH105>3.0.CO;2-7

Tosun, C. (2002). Host perceptions of impacts: A comparative tourism study. Annals of Tourism Research, 29(1), 231-253. https://doi.org/10. 1016/S0160-7383(01)00039-1

Vargas-Sánchez, A., Porras-Bueno, N., \& de los Ángeles Plaza-Mejía, M. (2011). Explaining residents' attitudes to tourism: Is a universal model possible? Annals of Tourism Research, 38(2), 460-480. https://doi. org/10.1016/j.annals.2010.10.004

Williams, J., \& Lawson, R. (2001). Community issues and resident opinions of tourism. Annals of Tourism Research, 28(2), 269-290. https://doi. org/10.1016/S0160-7383(00)00030-X

Wong, J. D. (1996). The impact of tourism on local government expenditures. Growth and Change, 27(3), 313-326. https://doi.org/10. 1111/j.1468-2257.1996.tb00908.x

Woosnam, K. M. (2012). Using emotional solidarity to explain residents' attitudes about tourism and tourism development. Journal of Travel Research, 51(3), 315-327. https://doi.org/10.1177/0047287511410351 
DRUŠ. ISTRAŽ. ZAGREB GOD. 28 (2019), BR. 1 STR. 131-151

PEŠTEK, A. ET AL. RESIDENTS' ATTITUDES...

\section{Stavovi stanovništva o razvitku turizma: studija slučaja Federacije} Bosne i Hercegovine

Almir PEŠTEK

Ekonomski fakultet, Sarajevo

Lejla DIZDAREVIĆ

Međunarodno sveučilište u Sarajevu, Sarajevo

Marijana GALIĆ

Federalni zavod za programiranje razvoja, Sarajevo

Melika ARIFHODŽIĆ

Fakultet političkih znanosti, Sarajevo

$U$ istraživanju se analiziraju percepcije i stavovi koje stanovništvo ima prema razvoju turizma u Federaciji Bosne i Hercegovine (FBiH). Za ovo istraživanje modificirani su postojeći modeli o percepcijama i stavovima stanovništva, a testiran je i novi teoretski model sa šest konstrukata uz primjenu konfirmatorne faktorske analize. Dimenzije modela percepcija o upravljanju turizmom, percepcija o ekonomskim, socijalnim i okolišnim učincima, zadovoljstvo stanovništva, podrška budućem razvoju turizma formirane su kao latentne varijable koje prate skup odgovarajućih pitanja. Model sugerira da je podrška razvoju turizma neizravno uvjetovana percepcijom o upravljanju turizmom, kao i o ekonomskim i socijalnim učincima te utjecaju na okoliš. Rezultati analize potvrdili su 6 od 7 postavljenih hipoteza, pokazujući da stanovništvo $\mathrm{FBiH}$ snažno podržava razvoj turizma s obzirom na to da donosi više pozitivnih učinaka, koji su veći od stvarnog ulaganja vlade u sektor turizma.

Ključne riječi: percepcija i stavovi stanovništva, razvoi turizma, lokalna zajednica, Federacija Bosne i Hercegovine

\section{(c) (1) (8)}

Međunarodna licenca / International License:

Imenovanje-Nekomercijalno/ Attribution-NonCommercial 